\title{
Ecotoxicity of Biocides (Chemical Disinfectants) - Lethal and Sublethal Effects on Non-target Organisms
}

\author{
STEFANIA GHEORGHE\#, CATALINA STOICA\#, IRINA LUCACIU, ALINA BANCIU, MIHAI NITA LAZAR* \\ National Research and Development Institute for Industrial Ecology ECOIND, 71-73 Drumul Podu Dambovitei Str., 060652, \\ Bucharest, Romania
}

\begin{abstract}
The aim of this paper was to assess de ecotoxicity effects of four biocides, used as chemical disinfectants for swimming pool water treatment, on non-target organisms such as Daphnia magna and Heterocypris incongruens crustaceans. The tests showed a significant difference of sensitivity between species. The biocides, at the recommended disinfection doses, induced a very toxic or toxic effect on Daphnia magna, based on their mortality percentage. On the contrary, the observed ostracods lethal effects were generally less than 50\% mortality and no significant growth inhibitions were observed. Overall, the ostracods had a higher tolerance to subacute doses, including disinfection doses of $20 \mathrm{mg} / \mathrm{L}$ (potassium mono persulfate), $5 \mathrm{mg} / \mathrm{L}$ (sodium dichloroisocyanurate), $8 \mathrm{mg} / \mathrm{L}$ (trichloroisocyanuric acid $90 \%$ ) and $7 \mathrm{mg} / \mathrm{L}$ (trichloroisocyanuric acid 87-88\%). In the context of a continuous biocides market expansion, the paper highlighted that our research proposed testing methods to obtain fast and accurate ecotoxicity data for a sustainable biocide production / authorization and also for an environmental hazard assessment.
\end{abstract}

Keywords: biocide, ecotoxicity, crustaceans, ostracods

Biocide have a large application in different human activities like food industry, medicine, farming, water treatment, household products and cosmetics. Biocides have been designed for specific targets, so they have been classified in function of their specificity in: pesticides (such as fungicides, insecticides, algaecides, molluscicides, miticides and rodenticides) and antimicrobial (such as bactericides, antibiotics, antivirals, antifungals, antiprotozoals, germicides, antiparazites, spermicides) [1]. Unfortunately, their uncontrolled use and an inefficient wastew ater treatment (due to the fact that the wastewater treatment plants have not been designed to remove those chemical compounds) made possible a high occurrence of biocides in freshwaters. These compounds have been found in wastewater effluents, sludge, natural waters, sediments and even in drinking water [2, 3].

In Europe, the market of biocides is in expansion even higher than the antibiotics market. In spite of a Biocides Regulation 528/2012, which covers the authorization process and placing of biocide products on market, the exact amount of biocide production [4], usage and environmental presence is not very well under control. Therefore, the biocides must be tested for their toxic efficacy, human and environmental safety, control of their residues and degradation products.

According to Guidance on the Biocidal Regulation: Volume IV Environment, PartA Information Requirements, the biocides risk assessment needs to be evaluated for their aquatic effects in different compartments and in multispecies experimental settings [5]. The evaluations, respectively the quantification of the predicted of no effects concentrations - PNEC values, are based on the most sensitive taxonomic group considering the short term or long term effects. Generally, it has been shown that biocides generate acute toxicity on vertebrate and invertebrate organisms (such as cytotoxic, genotoxic and endocrine disruptor effects) [2] and photosynthetic system inhibition in case of algae or aquatic plants [6]. In spite of the fact that disinfection agents are biodegradable, the chlorination process, biological methylation or photo oxidation, could transform the biocides in more toxic and persistent compounds leading to resistance in microbial communities $[2,7,8]$ that can affect the swimmers or consumers and subsequently the freshwater ecological status [9]. In addition, since the biocides have been used as chemical disinfectants for water disinfection such as swimming pool water, drinking water, wastewater, the disinfection practice increased the concern of toxic effects on non-target organisms.

It was reported that microorganisms $[10,11]$ and invertebrates have been frequently used in environmental toxicity evaluation of chemicals [12]. Among the invertebrates, Daphnia magna crustaceans have been the most used indicator of the effects of xenobiotics on primary consumers in freshwater ecosystems [13-16]. Also, is known that benthic invertebrates are more susceptible to dissolved and undissolved pollutants than pelagic biota, and may serve as an environmental imbalance long term marker [17-20].

The paper aim was to assess the toxic effects generated by four antimicrobial biocides (used in swimming pool water disinfection) on two type of non-target aquatic organisms-Daphnia magna and Heterocypris incronguens.

\section{Experimental part \\ Materials}

All tested biocides products were chemical disinfectants used for swimming pool water disinfection in Romania (table 1). The products were noted as biocide 1, biocide 2 , biocide 3 and biocide 4 . Biocide 1 was based on potassium mono persulfate (or potassium peroxymonosulfate) an oxidizing agent that releases free sulfate radicals and free hydroxyl radicals with high activity in water less toxic than chlorine disinfection. This substance is being used for disinfection, veterinary hygiene, food and animal feeds and drinking water sanitation [21].

Biocide 2 was based on sodium dichloroisocyanurate dihydrate (or sodium troclosene, sodium 3,5-dichloro-2,4,6- 
Table 1

CHEMICALS INFORMATION [22]

\begin{tabular}{|c|c|c|c|c|c|}
\hline \multirow{2}{*}{$\begin{array}{l}\text { Biocide } \\
\text { products }\end{array}$} & \multirow{2}{*}{ Active substances } & \multirow{2}{*}{$\begin{array}{c}\text { CAS } \\
\text { number }\end{array}$} & \multicolumn{2}{|c|}{$\begin{array}{l}\text { Dose for water treatment } \\
(\mathrm{mg} / \mathrm{L})\end{array}$} & \multirow{2}{*}{$\begin{array}{c}\text { Chemical formula } \\
\text { 2D }\end{array}$} \\
\hline & & & Shock dose & $\begin{array}{c}\text { Maintenance } \\
\text { dose }\end{array}$ & \\
\hline Biocide 1 & $\begin{array}{c}\text { Potassium mono } \\
\text { persulfate / potassium } \\
\text { peroxymonosulfate } 100 \%\end{array}$ & $70693-62-8$ & 20 & 12 & \\
\hline Biocide 2 & $\begin{array}{c}\text { Sodium } \\
\text { dichloroisocyanurate } \\
\text { troclosene } 100 \%\end{array}$ & $51580-86-0$ & $3-5$ & $1.8-3.6$ & $\Theta_{\cdots \mathrm{Na}}^{\oplus}$ \\
\hline Biocide 3 & $\begin{array}{c}\text { Trichloroisocyanuric } \\
\text { acid / simclosene } 90 \% \\
\text { and aluminum sulfate } 3 \% \text {, } \\
\text { copper sulfate } 2 \% \text {, boric } \\
\text { acid } 1.9 \%\end{array}$ & $87-90-1$ & - & 8 & \\
\hline Biocide 4 & $\begin{array}{c}\text { Trichloroisocyanuric } \\
\text { acid } / \text { simclosene } 87-88 \% \\
\text { and aluminum sulfate } 3- \\
4 \% \text {, copper sulfate } 1-2 \% \text {, } \\
\text { boric acid } 2 \%\end{array}$ & $87-90-1$ & - & 7.14 & 6 \\
\hline
\end{tabular}

Table 2

TOXICITY METHODS

\begin{tabular}{|c|c|c|c|c|}
\hline $\begin{array}{c}\text { Non-target } \\
\text { organisms }\end{array}$ & Method & Materials & Method adjustment & $\begin{array}{l}\text { Toxicity end } \\
\text { points }\end{array}$ \\
\hline $\begin{array}{c}\text { Daphnia } \\
\text { magna }\end{array}$ & $\begin{array}{c}\text { ISO } 6341 \\
\text { OECD } 202 \\
\text { Acute toxicity } \\
(24 \mathrm{~h} \text { and } 48 \mathrm{~h})\end{array}$ & $\begin{array}{c}\text { Daphtoxkit F } \\
\text { magna * }\end{array}$ & \multirow{2}{*}{$\begin{array}{l}\text { To avoid the vaporization and } \\
\text { absorption in tested solutions, } \\
\text { each concentration was } \\
\text { individually tested }\end{array}$} & 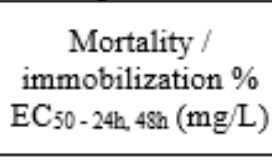 \\
\hline $\begin{array}{l}\text { Heterocypris } \\
\text { incongruens }\end{array}$ & $\begin{array}{l}\text { ISO } 14371 \\
\text { Subacute } \\
\text { toxicity } \\
\text { (6 days) }\end{array}$ & $\begin{array}{l}\text { Ostracodtoxkit } \\
\mathrm{F}^{*}\end{array}$ & & $\begin{array}{c}\text { Mortality } \% \\
\text { Growth inhibition } \\
\% \\
\text { EC }_{50-6 \text { days }}(\mathrm{mg} / \mathrm{L})\end{array}$ \\
\hline
\end{tabular}

$\mathrm{EC}_{50}$ - effective concentration for $50 \%$ of organisms; * kits supplied by MicroBiotests Inc. Belgia

trioxo-1,3,5-triazinan-1-ide) with many applications (based on chlorine release) as cleansing agent, biocide, industrial deodorant and also as disinfectant agent in water sanitation (drinking water or swimming pools) [23]. The active substance from biocides 3 and 4 is trichloroisocyanuric acid (1,3,5-trichloro-1,3,5-triazinane-2,4,6-trione) an organic compound used as disinfectant (also based on chlorine release), algaecide and bactericide especially in pools water treatment and also as a bleaching agent in textile industry, in civil sanitation, in animal husbandry and fisheries, fruit and vegetable preservation and others [24, 25]. All the active substances from the studied biocide products are listed as High Production Volume (HPV) chemicals.

The laboratory tests were performed using the reagents / growth media supplied by MicroBiotests Belgia [26, 27] and using the infrastructure, equipment and logistic support of Biotests Laboratory of National Research and Development Institute for Industrial Ecology ECOIND.

\section{Toxicity methods}

The ecotoxicity tests were performed on two type of aquatic organisms: Daphnia magna (water flea, planktonic crustaceans) and Heterocypris incongruens (ostracods, benthonic crustaceans). The organisms were selected according to Biocides Regulation requirements and also to cover two different aquatic compartments: water and sediment. Another reason of this selection was that Heterocypris incongruens and Daphnia magna are common species that inhabit shallow seasonal pools and small water bodies [28].

According to standardized procedure $[29,30]$ (table 2) the Daphnia magna neonates were exposed to a various concentrations of biocides during $24 \mathrm{~h}$ and $48 \mathrm{~h}$ in darkness at $20^{\circ} \mathrm{C}$. The mortality / immobilization results were analyzed on the stage of a light table. The data were used to calculate $50 \%$ effect threshold ( $\mathrm{EC}_{50}$ at $24 \mathrm{~h}$ and $48 \mathrm{~h}$ ) with the MBT Daphnia Regtox Program (HILL model).

The benthic ostracods Heterocypris incongruens (table 2) were directly exposed to an artificial contaminated sediment and their growth or mortality percentage were detected and compared to control results [31]. After six days in darkness at $25^{\circ} \mathrm{C}$, the biocides effects were evaluated. The ostracods handling and mortality analyze were made using a MOTIC stereomicroscope type DM143 FBGG-B with incorporated camera. For ostracods length measurements a stereomicroscope M205FA from 
Leica Microsystems (Schweiz) A (objectives 1x -work distance 61.5 and $2 x$ - work distance 20.1) with image processing software was used. The results were processed

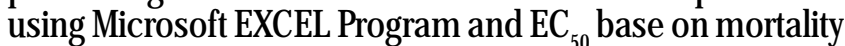
percentages at 6 days were analyzed. Standard deviation values were calculated for the mean length of ostracods.

The range of tested concentrations of each biocide was established according to the used doses and toxicity method requirements. At least five concentrations for each biocide were tested per each non-target organisms: biocide $1-0.25$ to $50 \mathrm{mg} / \mathrm{L}$; biocide $2-0.05$ to $12.5 \mathrm{mg} / \mathrm{L}$; biocide 3 and $4-0.01$ to $20 \mathrm{mg} / \mathrm{L}$. The tests were performed in replicates for each tested concentration and control to ensure statistically relevant results.

\section{Results and discussions}

Toxicity effect induced to Daphnia magna

During the first $24 \mathrm{~h}$ of biocide intoxication the neonates of planktonic crustaceans, Daphnia magna, showed an increased acute sensitivity expressed by percentages of immobilization / mortality (fig. 1). Lethal effects of $100 \%$ were observed at the lowest concentrations of $12 \mathrm{mg} / \mathrm{L}$ for biocide $1 ; 1.8 \mathrm{mg} / \mathrm{L}$ for biocide 2; and $0.1 \mathrm{mg} / \mathrm{L}$ in case of biocides 3 and 4 . Effects in control limits (0-10\% mortality) were observed for $0.5 \mathrm{mg} / \mathrm{L}$ - biocide $1(5 \%)$ and $0.05 \mathrm{mg} / \mathrm{L}$ in case of biocides 3 and 4 (10\%) (fig. 1).

Biocide 2 induced 15\% mortality at the lowest tested concentrations of $0.05 \mathrm{mg} / \mathrm{L}$. Water treatment doses of all studied biocide products highlighted total mortality of Daphnia magna. The same sensitivity of Daphnia magna to biocides (triclosan and triclorocarban -similar with the studied compounds) was showed also by other studies [3].

For instance, the results obtained for the biocide 2 (sodium dichlorizocyanurate), biocides 3 and 4 (trichloroisocyanuric acid) showed a different effect compared with biocide 1 (potassium mono persulfate).
Biocide 1, based on the release of active oxygen was less toxic for Daphnia magna compared to active chlorine based biocides (fig. 2). The value of $E C_{50}$ for the first $24 \mathrm{~h}$ of exposure was higher than $\mathrm{EC}_{50}$ after $48 \mathrm{~h}$, which showed a shock effect. The $\mathrm{EC}_{50}$ at $24 \mathrm{~h}$ were in the range of 0.058 $\mathrm{mg} / \mathrm{L}$ to $2.54 \mathrm{mg} / \mathrm{L}$. The $E C_{50}$ at $48 \mathrm{~h}$ showed the followed values: $10.45 \mathrm{mg} / \mathrm{L}$ for biocide $1,0.19 \mathrm{mg} / \mathrm{L}$ for biocide 2 , $0.068 \mathrm{mg} / \mathrm{L}$ for biocide 3 and 4 . Similar results for biocide 3 and 4 were obtained because of insignificant difference in concentrations of active substances that have not influenced the toxicity.

According to Regulation (EU) 286/2011 for modification of Regulation (CE) 1272/2008 [32], the biocide 1, 2 and 4 were classified as very toxic $\left(\mathrm{EC}_{5 \mathrm{f}-\mathrm{sh}} \leq 1 \mathrm{mg} / \mathrm{L}\right.$, risk phrase H 400 - very toxic for aquatic life). Biocide 1 based on potassium mono persulfate was classified as toxic $(1 \mathrm{mg} /$ $\mathrm{L}<\mathrm{CE}_{50 \text { ish }} \leq 10 \mathrm{mg} / \mathrm{L}$, risk phrase $\mathrm{H} 411$-toxic for aquatic life, with long term effects). The same class of toxicity were identified for Daphnis in literature. The toxicity values for biocide 1 ranged in the interval $2.5-5.3 \mathrm{mg} / \mathrm{L}$, for biocide 2 were between $0.11-0.42 \mathrm{mg} / \mathrm{L}$ and for biocide 3 and 4 were between $0.16-0.21 \mathrm{mg} / \mathrm{L}$ (fig. 2) [33].

\section{Toxicity effects induced to Heterocypris incongruens}

The direct contact sediment toxicity tests were carried out on neonates of benthic crustaceans Heterocypris incongruens. The bioassays could be considered a subacute test, because the testing period covers six days and growth of organisms is an evaluation criterion of toxicity. The ostracods revealed lethal effects in the range of $0-43 \%$ for biocide $1 ; 6-100 \%$ for biocide $2 ; 13-46 \%$ for biocide $3 ; 13$ $40 \%$ for biocide 4 (fig. 3).

The highest biocide concentrations showed more than $30 \%$ mortality on tested organisms. Effects in control limits (0-10\%) were observed in case of 0.25 and $1 \mathrm{mg} / \mathrm{L}$ biocide $1,0.25 \mathrm{mg} / \mathrm{L}$ biocide 2 , and $0.1 \mathrm{mg} / \mathrm{L}$ biocide 3 and 4 . Because of reduced toxic effects $(<50 \%)$ in case of biocide

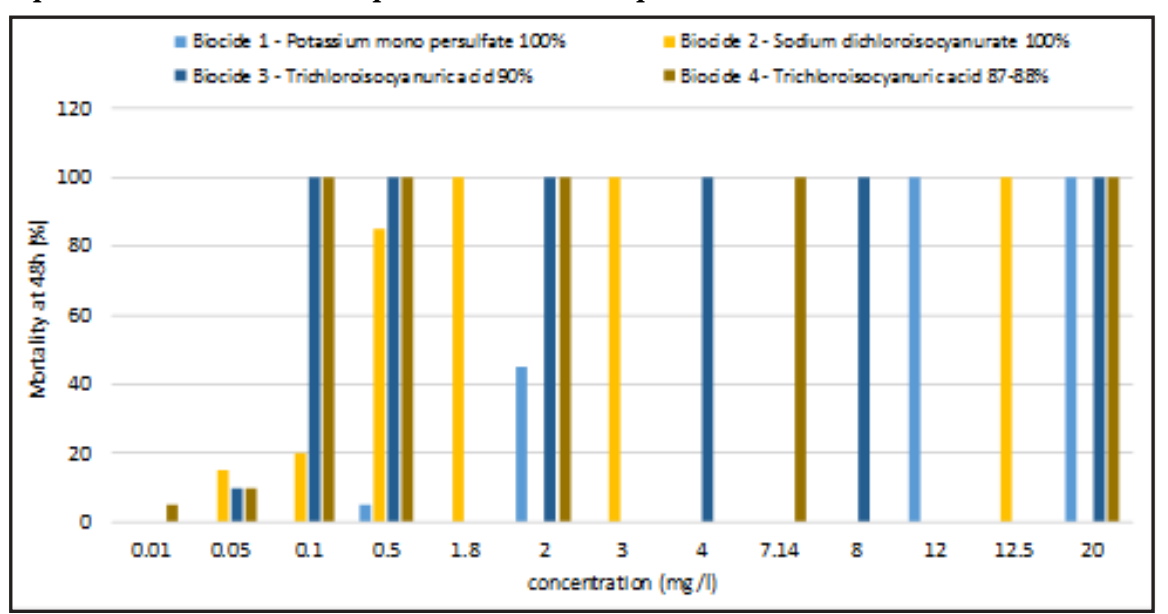

DEC5O(24h) DEC5O(48h)

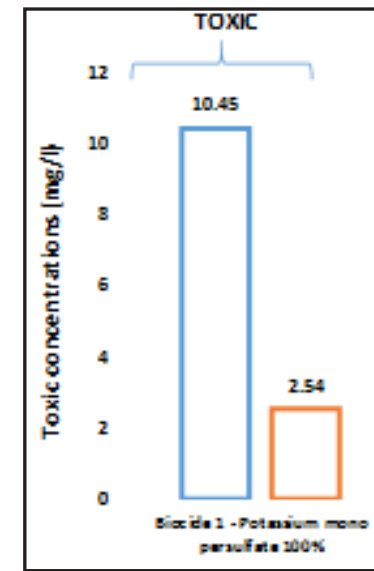

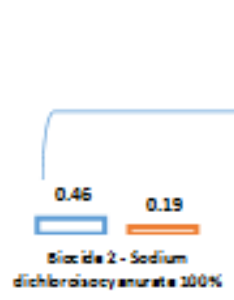

• 2019
VERRY TOXIC

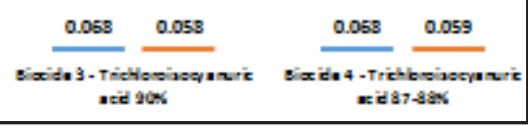

http://www.revistadechimie.ro

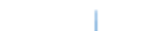

Fig. 1. Lethal effects of biocides on Daphnia magna at $48 \mathrm{~h}$

Fig. 2. $\mathrm{EC}_{50}$ of biocide $1,2,3$ and 4 on Daphnia magna 


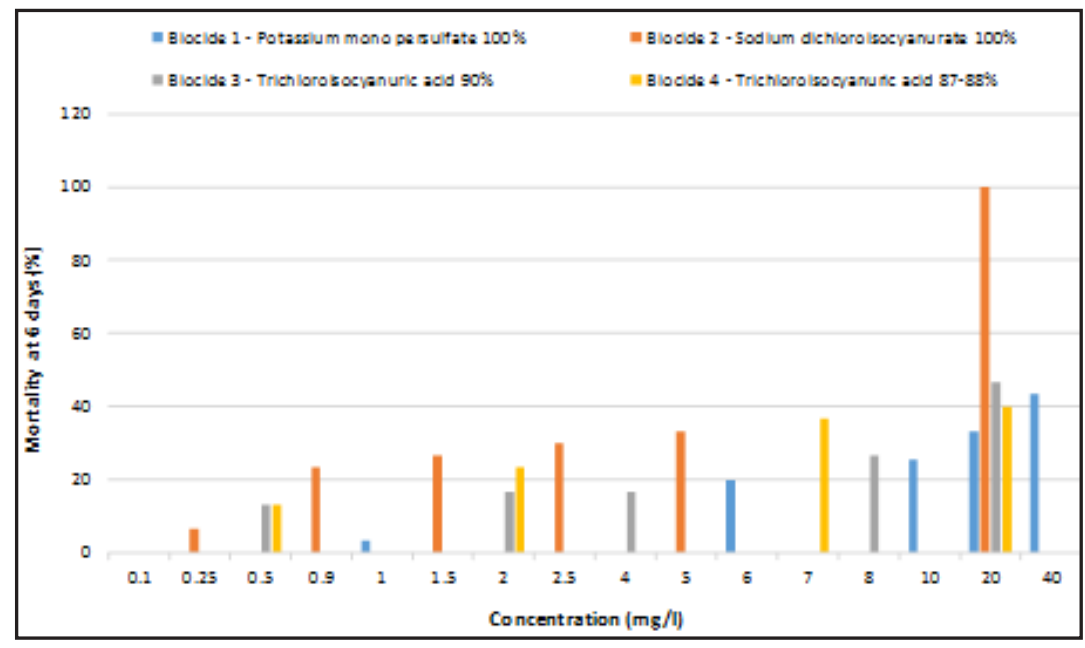

Fig. 3. Lethal effects (\%) of biocide on Heterocypris incongruens

1,3 and 4, the $\mathrm{EC}_{50}$ calculation was not possible, but it was estimated that $\mathrm{EC}_{50}$ could be more than $40 \mathrm{mg} / \mathrm{L}$ for biocide 1 and more than $20 \mathrm{mg} / \mathrm{L}$ for biocide 3 and $4 . \mathrm{EC}_{50}$ at 6 days for biocide 2 was $7.70 \mathrm{mg} / \mathrm{L}$ (classified as toxic for ostracods). The concentrations used by producer in pools water treatment highlighted $26-33 \%$ mortality on ostracods (fig. 3).

Heterocypris incongruens revealed a great resistance to tested biocides concerning the sub lethal effects. Growth inhibition was measured using the length of exposed ostracods compared with the control growth at 6 days. The ostracods mean length and the growth inhibitions values (\%) are presented in table 3.

The toxic effects on organism's growth were less than $30 \%$ in the range of $0.1-20 \mathrm{mg} / \mathrm{L}$ for all tested biocides.

Moreover, the smallest concentrations reveled an increasing growth of tested ostracods, this results being embedded in the control limits of $\pm 10 \%$ (fig. 4 - 7). For the concentrations of biocides used regularly for water treatment, the following effects were observed: $20 \%$ growth inhibition for biocide 1 and 2 (at $20 \mathrm{mg} / \mathrm{L}$ respectively $5 \mathrm{mg} / \mathrm{l}$ ), $16 \%$ for biocide 3 (at $8 \mathrm{mg} / \mathrm{L}$, fig. 3 ) and $8 \%$ in case of biocide 4 (at $7 \mathrm{mg} / \mathrm{L}$, fig. 4). Ostracods tolerance to pollutants was also reported in previous studies on benthic invertebrate [18,34,35]. Considering that Heterocypris incongruens prays the small organisms like Daphnia magna, the negative effects of biocide obtained for Daphnis could induce imbalances in ostracods communities [36].

Table 3

OSTRACODS MEAN LENGTH AND GROWTH INHIBITION

\begin{tabular}{|c|c|c|c|c|}
\hline $\begin{array}{l}\text { Biocide and tested } \\
\text { concentration }(\mathrm{mg} / \mathrm{L})\end{array}$ & $\begin{array}{c}\text { Control } \\
\text { mean length } \\
-\mu \mathrm{m}(0 \mathrm{~h})\end{array}$ & $\begin{array}{c}\text { Control } \\
\text { mean length } \\
-\mu \mathrm{m} \text { (6 days) }\end{array}$ & $\begin{array}{c}\text { Mean length } \\
\text { in test }-\mu \mathrm{m} \\
\text { (6 days) }\end{array}$ & $\begin{array}{c}\text { Growth } \\
\text { inhibition (\%) }\end{array}$ \\
\hline \multicolumn{5}{|c|}{ Biocide I- Potassium mono persulfate $100 \%$} \\
\hline 0.25 & \multirow{6}{*}{$214 \pm 10.51$} & \multirow{6}{*}{$619 \pm 8.58$} & $629 \pm 57.74$ & -2.57 \\
\hline 1 & & & $629 \pm 37.63$ & -2.54 \\
\hline 6 & & & $577 \pm 35.73$ & 10.31 \\
\hline 10 & & & $556 \pm 20.19$ & 15.58 \\
\hline 20 & & & $539 \pm 19.10$ & 19.72 \\
\hline 40 & & & $443 \pm 28.17$ & 43.35 \\
\hline \multicolumn{5}{|c|}{ Biocide 2 - Sodium dichloroisocyanurate 100\% } \\
\hline 0.25 & \multirow{5}{*}{$214 \pm 10.51$} & \multirow{5}{*}{$619 \pm 8.58$} & $709 \pm 27.94$ & -22.22 \\
\hline 0.9 & & & $647 \pm 77.84$ & -7.13 \\
\hline 1.5 & & & $626 \pm 25.56$ & -1.70 \\
\hline 2.5 & & & $616 \pm 26.12$ & 0.58 \\
\hline 5 & & & $393 \pm 7.31$ & 19.56 \\
\hline \multicolumn{5}{|c|}{ Biocide 3 - Trichloroisocyanuric acid $90 \%$} \\
\hline 0.1 & \multirow{6}{*}{$249 \pm 10.49$} & \multirow{6}{*}{$493 \pm 34.41$} & $523 \pm 13.5$ & -7.23 \\
\hline 0.5 & & & $507 \pm 48.87$ & -5.42 \\
\hline 2 & & & $497 \pm 11.26$ & -1.60 \\
\hline 4 & & & $469 \pm 17.52$ & 9.81 \\
\hline 8 & & & $455 \pm 13.02$ & 15.89 \\
\hline 20 & & & $420 \pm 8.64$ & 29.89 \\
\hline \multicolumn{5}{|c|}{ Biocide 4 - Trichloroisocyanuric acid $87-88 \%$} \\
\hline 0.1 & \multirow{5}{*}{$249 \pm 10.49$} & \multirow{5}{*}{$493 \pm 34.41$} & $494 \pm 63.12$ & -0.25 \\
\hline 0.5 & & & $497 \pm 30.32$ & -1.59 \\
\hline 2 & & & $498 \pm 30.92$ & -1.97 \\
\hline 7 & & & $474 \pm 63.49$ & 7.90 \\
\hline 20 & & & $425 \pm 10.24$ & 27.95 \\
\hline
\end{tabular}




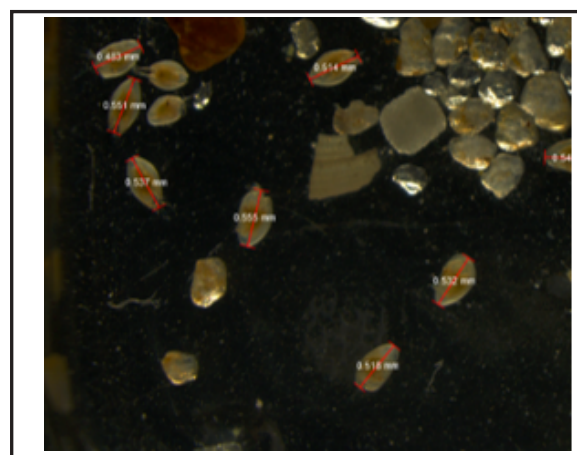

Fig. 4. Control at 6 days ( $1 \mathrm{X}, 2 \mathrm{~mm})$

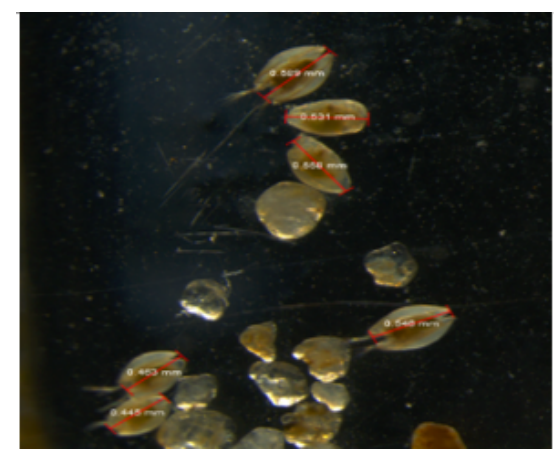

Fig. 6 . Biocide $4(7 \mathrm{mg} / \mathrm{L})$ at 6 days

$(1 X, 1 \mathrm{~mm})$

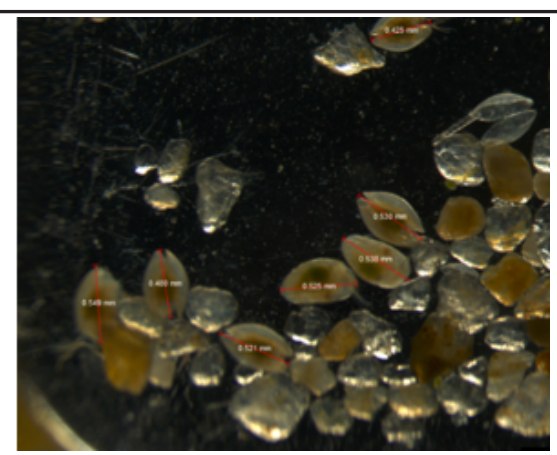

Fig. 5 . Biocide $3(8 \mathrm{mg} / \mathrm{L})$ at 6 days $(1 X, 1 \mathrm{~mm})$

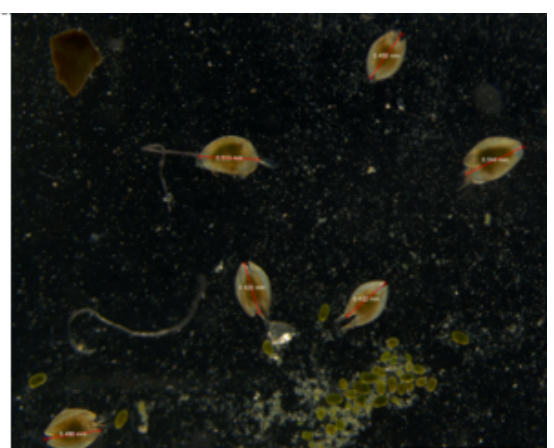

Fig. 7. Biocide $4(0.5 \mathrm{mg} / \mathrm{L})$ at 6 days

$(1 \mathrm{X}, 1 \mathrm{~mm})$

\section{Conclusions}

The lethal and sublethal effects of four biocides (chemical disinfectants) from the Romanian market were evaluated on non-usually targeted aquatic organisms. Biocides toxicity was analyzed on tw o crustacean species (Daphnia magna and Heterocypris incongruens) from pelagic and benthic compartments of the aquatic ecosystem. The tests showed a significant difference of sensitivity between Daphnia magna and Heterocypris incongruens. Considering the percentage of mortality, the biocides induced a very toxic or a toxic effect on Daphnia magna. A $100 \%$ mortality of Daphnis was observed in case of the concentrations recommended by producer in swimming pool water treatment. Contrary to Daphnia spp., the ostracods lethal effects were less than $50 \%$ for biocide 1 (potassium mono persulfate) and 3 and 4 (trichloroisocyanuric acid). The exposure of ostracods to biocide 2 (dichloroisocyanurate dehydrate) reveled toxic effects. Also, no significant growth inhibition was observed in the tested concentrations range. Recommended doses reveled an ostracods mortality in range of $26-33 \%$ and a growth inhibition betw een 8 to $20 \%$, indicating tolerance at tested concentrations. No significant toxicity differences were observed between biocide 3 and 4 , the percentage of active substances being insignificant. The toxicity magnitude was in accordance to concentration increasing for the both species. The laboratory tests create the most unfavorable situation for biocide exposure, but in the field the majority of biocide are biodegradable, their degradation compounds could be harmful for another organism. In order to avoid the toxic effects of the biocide doses (recommended by the producer) on small crustaceans, the receiving water should assure a dilution factor of about 100 in case of biocide 1 and 2 and 200 for biocide 3 and 4 . The ecotoxicity evaluation strategies on non-target organisms are not yet in trend with the continuous expansion of biocide market.

The European Commission is working since 2008 to create a Sustainable Consumption and Production and
Sustainable Industrial Policy Action Plan that should improve the environmental performance of products and increase the demand for more sustainable goods and production technologies by 2030. In this context, the paper highlighted that the Romanian laboratory could perform the tests required to obtain ecotoxicity data for a sustainable biocide production / authorization and also for environmental hazard assessment.

Acknowledgments: The present research was financially supported by the Romanian National Nucleu Program (code PN 18-05 02 01).

\section{References}

1.*** SCENIHR - EU Scientific Committee on Emerging and Newly Identified Health Risks Assessment of the Antibiotic Resistance Effects of Biocides, 2009.

2.BEDOUX, G., ROIG, B., THOMAS, O., DUPONT, V., LE BOT, B., Environ. Sci. Pollut. Res. Int., 19, no.4, 2012, p.1044.

3.CHALEW, T. E., HALDEN, R. U., J. Am. Water. Works. Assoc., 45, no.1, 2009, p. 4.

4.*** ECHA (2014) Transitional Guidance on Regulation (EU) No 528/ 2012 of the European Parliament and of the Council of 22 May 2012 concerning the making available on the market and use of biocidal products (Biocidal Products Regulation, the BPR). European Chemicals Agency, Helsinki, Finland, May 2014.

5.*** Guidance on the Biocidal Products Regulation Volume IV Environment - Assessment and Evaluation (Parts B $+C$ ) Version 2.0, October 2017.

6.MEREL, S., BENZING, S., GLEISER, C., DI NAPOLI-DAVIS, G., ZWIENER, C., Environ. Pollut., 239, 2018, p. 512.

7.(CATRANGIU) BANCIU, A., NICULESCU, D., NITA-LAZAR, M., LUCACIU, I., STOICA, C, MIHAESCU, G., J. Environ. Prot. Ecol., 17, no.1, 2016, p.127.

8.NITA-LAZAR, M., GHEORGHE, S., ANGHELACHE, A., BANCIU, A., STOICA, C., LUCACIU, I., Rev. Chim. (Bucharest), 67, no. 8, 2016, p. 1454.

9.STOICA, C., CAMEJO, J., BANCIU, A., NITA-LAZAR, M., PAUN, I., CRISTOFOR, S., ROCHA PACHECO, O., GUEVARA LOPEZ, M., Water. Sci. Technol.,73, no. 10, 2016, p. 2413. 
10.NITA-LAZAR, M., GALAON, T., BANCIU, A., PAUN, I., STOICA, C., LUCACIU, I., J. Environ. Prot. Ecol., 17, no. 1, 2016, p.237.

11.LAZAR, M.N., GHEORGHE, S., ANGHELACHE, A., BANCIU, A., STOICA, C., LUCACIU, I., Rev. Chim. (Bucharest), 67, no.8, 2016, p.1454.

12.CRAIOVEANU (IANOS), M. G., GHEORGHE, S., LUCACIU, I., STOICA, L., CONSTANTIN, C., Rev. Chim. (Bucharest), 65, no. 3, 2014, p.339. 13.MANKIEWICZ-BOCZEK, J., NAL ECZ-J AWECKI, G., DROBNIEWSKA, A., KAZA, M., SUMOROK, B., IZYDORCZYK, K., ZALEWSKI, M., AND SAWICKI, J., Ecotox. Environ. Safe. 71, no. 3, 2008, p. 830.

14.PERSOONE, G., BAUDO, R., COTMAN, M., BLAISE, C., THOMPSON, K., CL., MOREIRA-SANTOS, M., VOLLAT, B., TÖRÖKNE, A., HAN, T., Knowl. Manag. Aquat. Ecosyst., 393, 2009, p. 01.

15.GHEORGHE, S., LUCACIU, I., AND GRUMAZ, R. 2010. Proceedings of Inter. Conf. SGEM, J un. 21-26, 2010, Albena, Bulgary, 2, p.669.

16.GHEORGHE, S., PETRE, J., LUCACIU, I., STOICA, C., NITA-LAZAR, M., Environ. Monit. Assess., 188, no. 6, 2016, p. 379.

17.CAIRNS, J. J R., PRATT, J R., Freshwater biomonitoring and benthic macroinvertebrates, Rosenberg, D.M., and Resh, V.H., Eds., Chapman and Hall, New York, 1993, p. 10.

18.STOICA, C., GHEORGHE, S., LUCACIU E.I., STANESCU, E., PAUN, C. I., NICULESCU, L. D., Soil. Sediment. Contam., 23, no. 7, 2014, p. 763 19.STOICA, C., GHEORGHE, S., PETRE, J., LUCACIU, I., NITA-LAZAR, M., Environ. Eng. Manage. J., 13, no. 9, 2014, p. 2243.

20.DINU, C., UNGUREANU, E.M., VASILE, G.G., KIM, L., IONESCU, I. ENE, C., SIMION, M., Rev. Chim. (Bucharest), 69, no.1, 2018, p. 14. 21.MINGSONG, WU., XINYANG, XU., XUN, XU., AMM, 707, 2014, p.259. 22.*** https://pubchem.ncbi.nlm.nih.gov, accessed in 03.12.2018. 23.HUTHMACHER, K., MOST, D., (2000). Ullmann's Encyclopedia of Industrial Chemistry. Weinheim: Wiley-VCH, 2000, p. 9.

24.BARROS, J. C., Synlett. 13, 2005, p. 2115.
25.0'NEIL, M.J., (ed.). The Merck Index - An Encyclopedia of Chemicals, Drugs, and Biologicals. Whitehouse Station, NJ: Merck and Co., Inc., 2006., p. 1657.

26.*** Ostracodtoxkit $\mathrm{F}$-Direct contact toxicity test for fresh water sediments-standard operational procedure http://www.mi crobiotests.be/toxkit-microbiotests/test-protocols.

27.*** Daphoxkit F magna -Crustacean toxicity screening test for fresh water - standard operational procedure http://www.microbiotests.be/ toxkit-microbiotests/test-protocols.

28.ROSSI, V., BENASSI, G., BELLETTI, F., MENOZZI, P., J. Limnol., 70, no.1, 2011, p. 102.

29.*** OECD (2004) Guideline for the Testing of Chemicals, No. 202: Daphnia sp., Acute Immobilization Test. Adopted 13 April, 2004. Organization for Economic Co-Operation and Development, Paris 30.*** ISO 6341:2012 Water quality Determination of the inhibition of the mobility of Daphnia magna Straus (Cladocera, Crustacea) Acute toxicity test

31.*** ISO 14371 Water Quality Determination of fresh water sediment toxicity to Heterocypris incongruens (Crustaceea, Ostracoda) 32.*** Regulation (EC) No 1272/2008 of the European Parliament and of the Council of 16 December 2008 on classification, labelling and packaging of substances and mixtures, amending and repealing Directives 67/548/EEC and 1999/45/EC, and amending Regulation (EC) No $1907 / 2006$.

33.*** https://echa.europa.eu, accessed in 03.12.2018.

34.WANG, N., INGERSOLL, C.G., KUNZ, J.L., BRUMBAUGH, W.G., KANE, C.M., EVANS, R.B., ALEXANDER, S., WALKER, C., AND BAKALETZ, S. Environ. Toxicol. Chem., 32, no. 1, 2013, p. 207.

35.DI TORO, D.M, Environ. Toxicol. Chem., 32, no.1, 2013, p.7. 36.MILIEIC, D. M., MAJSTOROVIC, A. P., PAVKOVIC-LUĖIC, S. B., SAVIC, T. T., Crustaceana, 88, no. 10-11, 2015, p. 1097.

Manuscript received: 12.08 .2018 